\title{
Institutional incentives in circular economy transition: The case of material use in the Dutch textile industry
}

\author{
Aglaia Fischer a, Stefano Pascucci a, b, * \\ ${ }^{a}$ Management Studies Group, Wageningen University, The Netherlands \\ ${ }^{\mathrm{b}}$ Sustainability and Circular Economy, University of Exeter Business School, UK
}

\section{A R T I C L E I N F O}

\section{Article history:}

Received 16 December 2015

Received in revised form

7 December 2016

Accepted 9 December 2016

Available online $\mathrm{xxx}$

\begin{abstract}
A B S T R A C T
The aim of this paper is to gain insight into how requirements for transitioning to circular economy creates new organizational forms in inter-firm collaborations, and ultimately how they stimulate the emergence of new institutions enhancing sustainability. Two strands of literature, one on circular economy and one on institutional analysis, provide the theoretical background for this research. Currently a clearly formulated and unified theory on the institutions of circular economy is lacking. Therefore this research compares and contrasts empirical evidence from cases derived from the textile industry in The Netherlands, and concepts derived from institutional analysis and literature on circular economy to inductively build a cohesive conceptual framework. Using information from cases we identified two pathways to transition into circular economy and to manage circular material flows. We define these pathways Status Quo arrangements (SQ), when firms focus on optimizing up-cycling technologies and infrastructure in their circular relations and collaborations, and Product as Service arrangements (PAS), to indicate a focus on providing products in service contracts. Chain coordination, contracting, and financial mechanisms were identified as key organizational elements for creating new pathways to transition into circular materials flows. However in analyzing these elements we also highlight differences between SQ and PAS arrangements. SQ arrangements may have implications at the level of formal rules, for example by creating a new industry standards for up-cycled fabrics. PAS arrangements may have wider implications, for example by reshaping ownership in service contracts and creating cascading activities. Moving ownership to the supply chain will result in increased responsibility for materials and will create an incentive for improving quality of products, including their environmental performance. This is expected to generate positive socio-environmental impacts at a system level as well. Moreover PAS arrangements may have bottom up effects at a formal institutional level, resulting in alteration and creation of formal rules, for example in terms of new approaches to the ownership of materials.
\end{abstract}

(c) 2016 Elsevier Ltd. All rights reserved.

\section{Introduction}

The current linear system of ever increasing production, consumption, and economic growth is coming to an end (Ghisellini et al., 2016). In fact, this system is running out of resources, causing price volatility, uncertainties, and economic crises (Ellen McArthur Foundation, 2013). Besides the economic urgency for change, the linear approach to production and consumption is causing deterioration of the ecosystems due to climate change and environmental pollution (Groot et al., 2002; Barker, 2007). In other

\footnotetext{
* Corresponding author. Management Studies Group, Wageningen University, The Netherlands.

E-mail address: stefano.pascucci@wur.nl (S. Pascucci).
}

words, one can conclude that our current system is neither capable of sustaining our economic prosperity (Ellen McArthur Foundation, 2013), nor provide the vital living conditions for human beings and all other animal species (Costanza et al., 1997; Ghisellini et al., 2016).

There has been a lot of theorizing about the way to solve this issue. Scholars have come up with different ways of mapping and decreasing firms' activities that are harmful to the environment (Lozano et al., 2014). Concepts like carbon footprint, life cycle assessment (LCA), zero emissions (Braungart et al., 2007), and ecoefficiency (Verfaillie and Bidwell, 2000) form the basis for frameworks that tackle the environmental degradation connected to firms' activities. All of these concepts are in one way or another 
concerned with using fewer resources and reducing emissions, i.e. being more efficient. They start from the status quo of the common linear, one-way flow of materials. First, materials are extracted from the earth, made into products, and finally, after being used, they are incinerated or landfilled (Braungart et al., 2007). Eco-efficiency attempts to minimize the speed, toxicity, and volume of these material flows, but it does not challenge the linear approach and disposal of materials at the end of the life cycle (Ghisellini et al., 2016). From an economic point of view, eco-efficiency can result in short term cost reduction because of these cutbacks. However, reducing costs as a result of using fewer materials would soon reach a limit, seeing as we still need food to eat, garments to wear, et cetera. Hence, in the long term, the concept of eco-efficiency is leading to the conclusion that the ecological objectives of zero waste and eco-efficiency cannot be unified with the economic objective of eternal growth (Braungart et al., 2007). To summarise, attempts to be more eco-efficient can result in (temporary) improvement, but do not provide a long-term solution.

In contrast to eco-efficiency, another type of solution to foster sustainability can be found in the principles of Circular Economy (Ellen McArthur Foundation, 2013). Circular Economy (CE) is an industrial economy aiming at enhanced sustainability through restorative intent and design (Ghisellini et al., 2016). One of the main principles of CE is 'waste is food'. This means that all materials and products that are used can be seen as a temporary depot of materials or nutrients that will become input for new products after their lifecycle (Tukker, 2013; van Weelden et al., 2016). In CE, the concept of waste is eliminated by carefully designing products and industrial processes in such a way that materials are perpetually flowing nutrients and managed in closed loops. These loops are also defined as industrial metabolisms (Ellen McArthur Foundation, 2013; Smol et al., 2015). When firms are part of a metabolism they engage in organizing industrial symbiosis, in which energy and/or materials flowing out from one firm/process can be used in another process and/or by another firm that is active in the metabolism (Ashton, 2008). In a circular metabolism, waste is designed out. Therefore CE can tackle the paradox of uniting economy and ecology by aiming at an intelligent design of products and processes. In circular metabolisms, materials maintain their status as a productive resource (Braungart et al., 2007).

The current linear economy however, creates institutional barriers that have to be overcome in order to transition in to a $\mathrm{CE}$ (Ghisellini et al., 2016). Institutions are rules that shape economic actors' decision-making, and they are at the core of how firms, consumers, and other stakeholders interact and collaborate at a more general level (Williamson, 2000, 2002). Transitioning from a linear into a circular economy requires the emergence of new rules which need to be aligned to CE principles and practices. For example when companies engage in a circular metabolism they have to deal with new forms of inter-firm collaborations ${ }^{1}$ which are typically related to a wide set of interdependencies and complexities (Grandori and Soda, 1995; Grandori, 1997). Therefore, transitioning into circular economy creates conditions to experiment with new organizational forms, to transact and collaborate, as well as reshape the way property rights, regulations, and laws are conceptualized, and ultimately to identify sustainable solutions (Lozano et al., 2014). Still, the main challenge is to understand how

\footnotetext{
1 In the context of this paper we consider an inter-firm collaboration a medium or long term agreement or partnership (typically with more than one year duration) among two or more firms. An inter-firm collaboration is based on relationships which are wider than just transactional exchanges between firms, and it involves governance mechanisms which are not fully determined by ownership or formal contracting (Grant and Baden-Fuller, 1995).
}

to facilitate this transition when constrained by an institutional system that is aligned with the status quo of a linear economy and particularly to understand the role of inter-firm collaborations in this process. In our view, the vacuum of rules and related constraints are the drivers that provoke strategic actors (e.g. firms, policy-makers, consumers) to design new rules and thus to behave as institutional entrepreneurs (Pacheco et al., 2010).

The aim of this paper is, therefore, to gain an insight into how requirements for transitioning to $\mathrm{CE}$ creates new organizational forms in inter-firm collaborations and ultimately how they stimulate the emergence of new institutions enhancing sustainability. Two strands of literature, one on CE and one on institutional analysis, provide the theoretical background for this research. Currently, a clearly formulated and unified theory on new organizational forms of CE is lacking. In order to theorize about these new organizational forms, we selected empirical evidence from cases on the Dutch textile industry. Globally, the textile industry is a debated industry because of its severe impact on the environment due to the consumption of an enormous amount of resources, as well as the generation of $5 \%$ of total waste in the world (www.textilelab.nl). The two most commonly used resources, cotton and polyester, represent $85 \%$ of global fibre production and amounted to a total production of 65 million tons in 2014 (www.circle-economy.com). These numbers are still rising because consumers, on average, are buying 'fast fashion', such as low-cost, low-quality garments that are produced in low-wage countries and are sold in high volumes in Western markets (Circle Economy, 2015; http://www.circleeconomy.com/textiles/). Fast fashion and an increasing amount of waste are issues of both social and environmental concern. Companies active in the fast fashion industry introduce new collections monthly in order to cater to their consumers (http://www.circleeconomy.com/textiles/). Due to the poor quality, garments are easily and frequently disposed of. In the Netherlands, UK, and the Nordics it is estimated that $61 \%$ of these discarded garments (postconsumer textiles), are lost in household waste, ending up in landfill or incineration. From the $39 \%$ of textiles that are collected, $84 \%$ is reused and $16 \%$ is recycled (FFACT, 2014). In reality, recycling means down-cycling ${ }^{2}$ and after a second life, for example as cleaning towels, textiles are still incinerated or landfilled. This means that although part of post-consumer textiles is recycled, this is not leading to circular material flows due to the down-cycling of materials. In contrast to this trend, in the Dutch textile industry several companies are pioneering processes of transition towards circular usage of materials by creating new organizational forms to collaboratively improve this industry (www.circle-economy.com/ case/circlemarket/).

This article compares and contrasts empirical evidence from selected cases operating in the Dutch textile industry with concepts derived from literature on CE and institutional analysis, while aiming to inductively build a cohesive conceptual framework. More specifically this paper aims at providing a key contribution to the literature on institutional analyses and sustainability by identifying and analysing differences between two types of pathways towards $\mathrm{CE}$, and by explaining how the organizational arrangements for these two pathways differ.

\section{Conceptual framework}

\subsection{Circular Economy}

The Ellen MacArthur foundation refers to $\mathrm{CE}$ as an industrial

\footnotetext{
2 Products and materials of lesser quality and reduced functionality (www wikipedia.org).
} 
economy that is restorative by intention, and relies on three principles: (i) waste is food (i.e. eradicate waste through careful design); (ii) no mixing of biological and technical materials; (iii) rely on renewable energy (Ellen McArthur Foundation, 2013). CE is strongly connected to the concept of cradle-to-cradle (C2C), and focuses on eco-effectiveness rather than eco-efficiency, aiming at creating 'cradle-to-cradle' materials flows (Braungart et al., 2007; Ghisellini et al., 2016). Although the capacity of C2C to achieve ecoeffectiveness in practice has been questioned (Toxopeus et al., 2015), what C2C inspires at a conceptual level into CE practitioners is not a call for minimizing material streams but more intelligent design of products and processes in such ways that their constitutive materials maintain their status as productive resources (Braungart et al., 2007). Products and industrial processes are designed in such a way that materials are nutrients in a perpetual flow of either biological or technical metabolisms (Smol et al., 2015). Biological nutrients are biodegradable materials that are safe to return to the biosphere to feed biological processes, such as food, cotton, and timber (Smol et al., 2015). Technical nutrients on the other hand, are materials that can remain in a closed-loop system of manufacturing, material recovery, and reuse (Tukker, 2013). These are often synthetic or mineral materials and are used in a lot of consumer goods such as electronics, furniture, and cars (Braungart and McDonough, 2002). The use of toxic materials should be omitted, especially from products that are consumed or returned to the bio cycle (Ellen McArthur Foundation, 2013). In an ideal $\mathrm{CE}$, products are designed while considering possibilities to reuse products, cascade (parts of) products, and to harvest pure materials at the end of a product's lifecycle (Ellen McArthur Foundation, 2013). Finally, required energy should always come from a renewable source.

Fig. 1 shows the loops in which (parts of) products and materials circulate and cascade in order to create and retain value. The position on the hill represents the added value (by technology, design, brand) being highest at the top- and lowest at the bottom of the hill. In other words, the value adding activities in the chain lead to a higher spot on the hill. It should be evidenced that in the linear approach the life cycle is shorter than in the circular one. As can be seen in Fig. 1a the value of a product in the linear approach reaches its maximum at the top of the hill then decreases rapidly.

The left hand side of the figure (Fig. 1a) represents the linear system as it is currently known: from taking materials (e.g. mining), to making (manufacturing and service provisioning), to using, consuming, and disposing of the product. In the linear system the lifecycle ends after the use-phase and is therefore shorter than in the circular system. In a CE approach on the contrary, products are carefully designed to be durable, modular, and recyclable on the material level, enabling a closed loop metabolism whilst retaining the largest possible amount of added value (Fig. 1b). In Fig. 1b the supply chain -as we know it in the current linear system-is still visible on the left side of the hill. However, activities on the top of the hill (the use phase) and the slope on the right hand (value recovery phase) are added, setting this approach apart from the linear one (Achterberg et al., 2016). Moreover, feedback loops on the right hand of the hill (Fig. 1b) lead back to stages on the left side of the hill. Therefore the life cycle of a product in a circular system can be extended over and over by applying cascading ${ }^{3}$ activities that add value after user life.

\footnotetext{
${ }^{3}$ Cascading of components and materials can be defined as "putting materials and components into different uses after end-of-life across different value streams and extracting, over time, stored energy and material 'coherence'. Along the cascade, this material order declines (in other words, entropy increases)" (Ellen McArthur Foundation, 2013; p. 25).
}

In circular material flows loops the value recovery phase is created by maintenance, reuse, refurbishing, remanufacturing, and recycling. Activities near the use phase need the least amount of energy to create value because the products only need (minor) alterations (Ellen MacArthur Foundation and McKinsey, 2014). At the same time, most of the added value of the product is preserved since the product or its parts are used again, rather than being disassembled or disposed of (www.circle-economy.com; Achterberg et al., 2016).

From an organizational standpoint, firms engaged in cyclical metabolisms are more interdependent because they also deal with increased complexity when compared to firms engaging in linear supply chain relations (Ashton, 2008, 2009), as is commonly observed in inter-firm networks and collaborations (Grandori, 2012). If we look in particular at the activities used to close cycles, such as cascading, we can see that interdependencies are created either because materials need to be jointly managed (pooled interdependency), or because complementary assets or competences need to be jointly applied to, for example, reuse and refurbish materials (intensive interdependency ${ }^{4}$ ). Simultaneously, interdependencies are created because a second firm can use the stream of output in another stage of the cycle. This is often defined as sequential interdependency or reciprocal interdependency if the involved material/resource is highly specific for the firms operating in the cycle (Grandori, 1997). Since industrial metabolisms can be made up of several firms and include a large number of processes and nutrients, actors involved in activities to close loops also deal with increased complexity in their decision making and the information they have to process and store (Korhonen, 2004; Ashton, 2008, 2009). Another important feature of CE is that, other than focusing on consuming fewer materials, as in eco-efficiency driven approaches, it also focuses on prolonging the use of materials and on avoiding use of toxic compounds, thus considering any material used in a cycle as being a healthy nutrient for new cycles. If we look at industrial processes through this lens, it implies that the used excess materials and end of life products (post-use), which are currently seen as waste streams, would become the input for other production processes (Smol et al., 2015). Being able to use materials over and again as a nutrient for new industrial cycles implies the capacity to unite a reduction of virgin materials with economic growth, thus allowing regenerative abundance. In other words, CE provides a strategy that recouples ecology and economy (Ellen McArthur Foundation, 2013; Ellen MacArthur Foundation and McKinsey, 2014).

\subsection{Institutional analysis}

Similar to the concept of industrial symbiosis, participation in circular metabolisms implies having to deal with a variety of interdependencies between organizations (Korhonen, 2001, 2004; Gallopoulos, 2006; Wassenaar, 2015). These pose the conditions for the emergence of novel organizational forms between firms, in which, similarly to any other inter-firm networking, collaboration is explored in order to take full advantage of a circular metabolism, whilst limiting its costs (Grandori, 2012). Thus, the main challenge faced by firms engaged in CE transition is to arrange collaboration and business relations, whilst being constrained by an institutional system that is aligned with the principles of linear economy. In other words, there is a vacuum of institutions, for instance in terms of

\footnotetext{
4 Typologies of interdependencies in inter-firm collaborations are extensively
} discussed in Grandori (1997). 


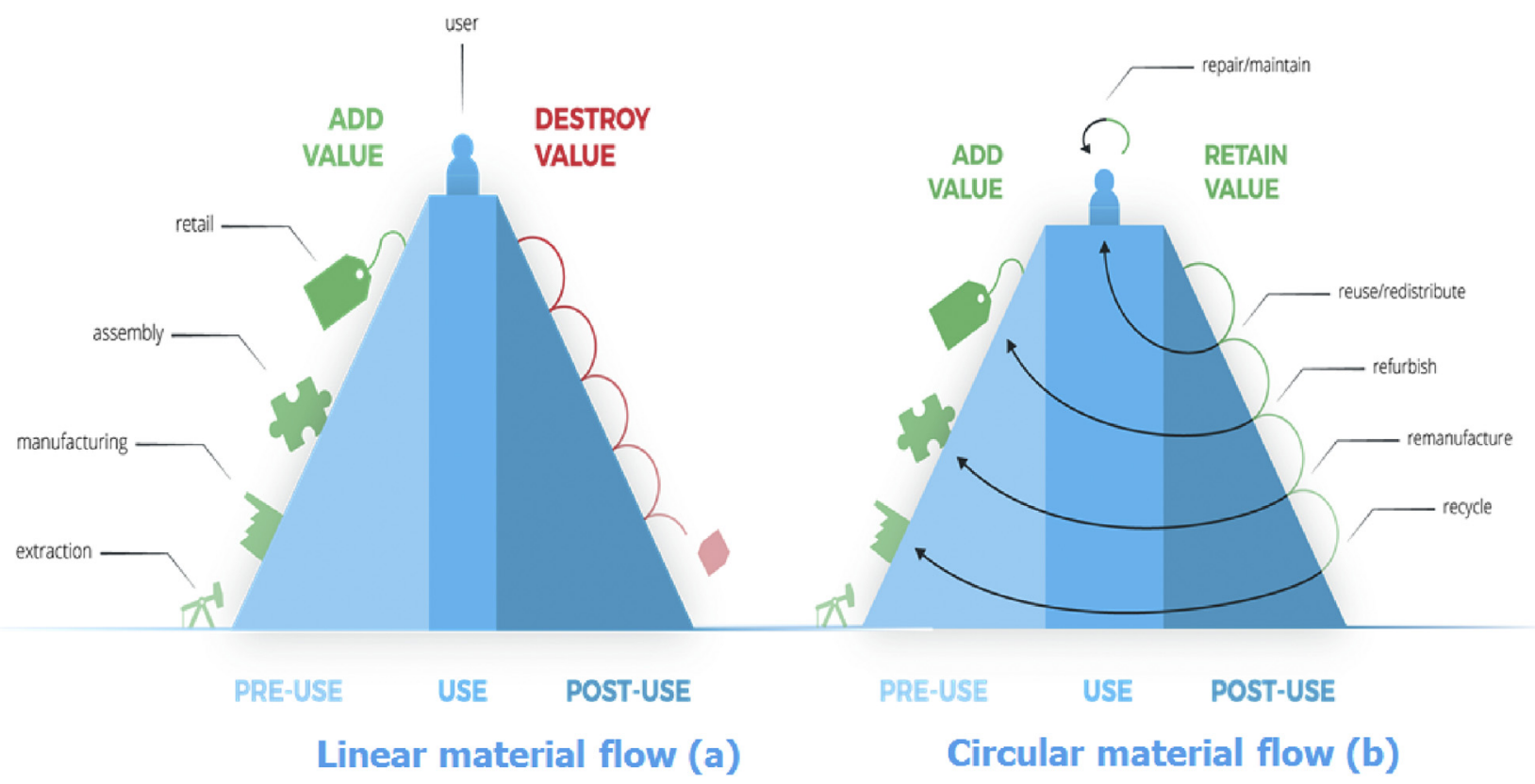

Fig. 1. Visualization of linear vs circular supply chain.

Source: adapted from Achterberg et al., 2016.

property rights, regulations, and (business) standards, which can sustain and facilitate inter-firm collaborations in circular metabolisms. Rules are needed because interdependencies are increased and become more specific as compared to collaborations in linear systems. As a consequence, actors (most importantly firms and consumers) engaged in CE transitions are increasingly more stimulated to act as institutional entrepreneurs (Pacheco et al., 2010; DiMaggio and Powell, 1983). As pointed out by Greif (1998), there is a relationship between organizational and institutional changes. More specifically new forms of organizations, such as contracts and arrangements between firms participating in circular metabolisms, can eventually result in altering more general rules in society, thus starting a process of transition at a wider scale (Dacin et al., 2002). To fully understand this process we adopt an institutional analysis perspective. Institutional analysis is a multidisciplinary framework that focuses on how the "rules of the game" of any socioeconomic system are defined (North, 1990; Ostrom et al., 1994; Ostrom, 1995; Greif, 1998; Williamson, 2000). Institutions are often seen as humanly devised constraints that shape interactions (North, 1990) and are considered to be key to structure incentives in human exchange (Coase, 1988; Williamson, 2000, 2002). As represented in Fig. 2, institutional changes and their analysis may be seen from a multi-level perspective. On the one hand institutions, such as informal rules (level 1 in Fig. 2) and/or formal rules (level 2 in Fig. 2) shape the way actors (inter)act and collaborate (Anderson and Hill, 2002, 2004) (level 3 in Fig. 2), and thus how they make decisions on resource allocation (level 4 in Fig. 2). On the other hand, it is often the case that actors can also change formal and informal rules through their resource allocation decisions and/or by adopting/promoting novel governance mechanisms. In this way they become "entrepreneurial" and mobilize resources required to change or transform institutions (Battilana et al., 2009; Pacheco et al., 2010) with the aim of exploiting economic opportunities that cannot be obtained in the current institutional system (Anderson and Hill, 2004). The question then remains how to categorize institutional changes related to the emergence of inter-firm collaborations in circular metabolisms.

Using a multi-level institutional analytic perspective, novel organizational forms can be seen as strategic situations ${ }^{5}$ in which actors engaged in circular metabolisms mobilize resources to alter the institutional status quo. Thus, within these collaborations, rules are set as self-enforcing constraints since they are not supported by any external enforcement (i.e. business standards, regulations, and property rights on materials) (Greif, 1998). As such, the unit of our analysis is novel organizational forms of inter-firm collaborations managing circular material flows, where the textile industry provides the micro empirical context of this analysis. Particularly we look at changes at the organizational level (inter-firm collaborations) which may re-shape institutions at a higher level, such as in terms of formalized rules (e.g. property rights on materials industry standards) and informal rules (e.g. trust and values related to material use and flows) (Greif, 1998).

\section{Methodology}

In line with the perspective of institutional analysis in this research, we follow an inductive approach and implement a methodological strategy based on using data grounded in a specific geographical and historical context (Greif, 1998). Particularly we perform a qualitative and explorative analysis based on a theory building from cases approach (Eisenhardt and Graebner, 2007), in which we use empirical evidence from multiple cases of inter-firm collaborations in circular material flows operating in the Dutch textile industry in order to depict the emergence of institutional changes. Building theory from case-based analyses is one of the most suitable methods to develop constructs and testable

\footnotetext{
${ }^{5}$ In general terms a strategic situation is a decision making context in which outcomes for each decision maker are depending not only on what he/she is doing but also on what the others are doing (Camerer, 1997). In the context of our research outcomes of strategic situations are rules emerging from collaborations among firms in circular metabolisms (materials flows) and enforcing these collaborations in future interactions.
} 


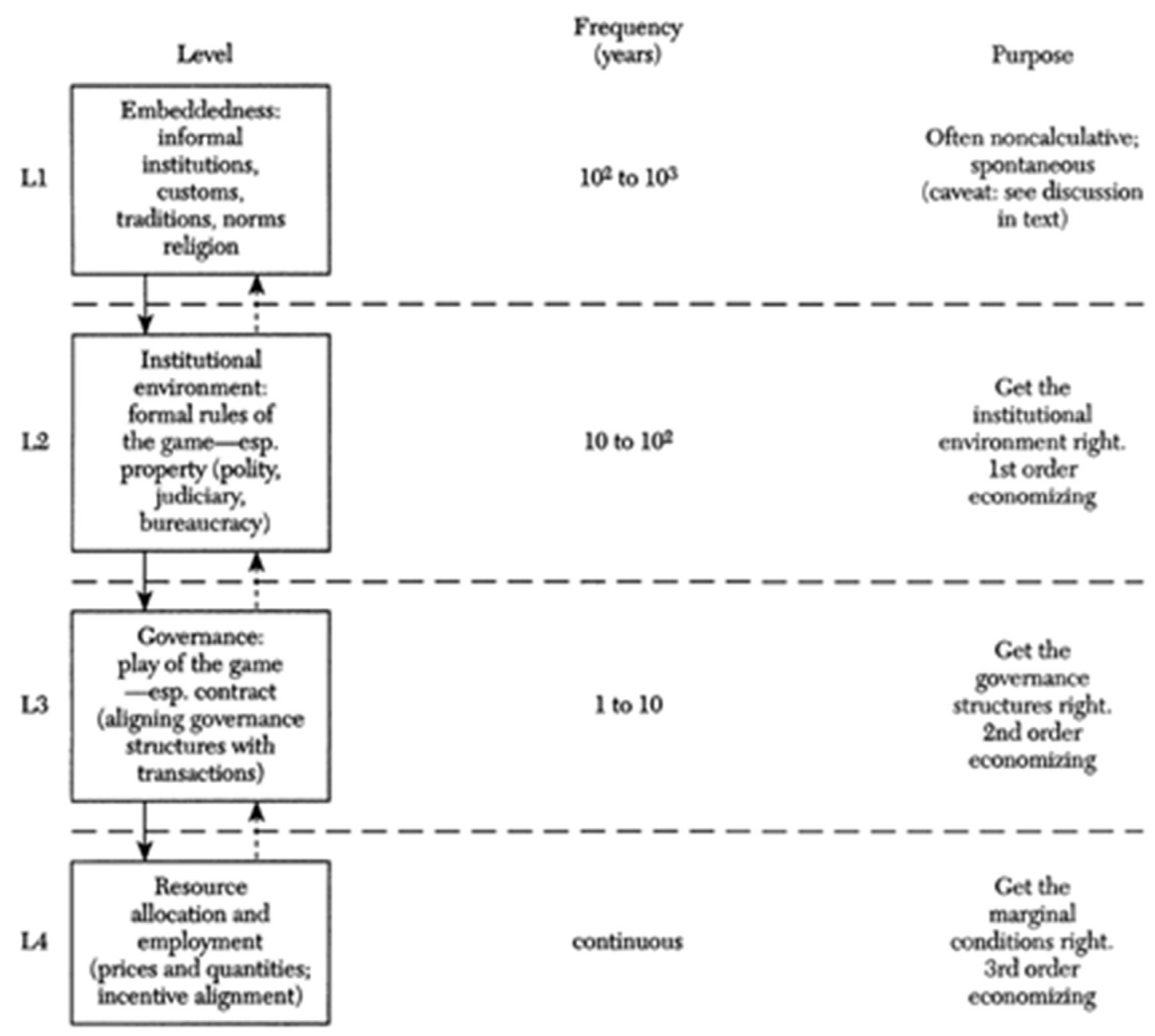

Fig. 2. A multi-level perspective to institutional analysis. Source: Williamson, 2000.

propositions for mainstream deductive research (Eisenhardt and Graebner, 2007) and widely used in the empirical tradition of institutional analysis contributions (Ostrom, 2011). Additionally, being deeply embedded in rich empirical data, building theory from cases often generates theory that is testable, accurate, and noteworthy (Eisenhardt and Graebner, 2007).

Since CE is a novel phenomenon and the identification of relevant strategic processes and actors in this domain is still limited, we see our analysis as preparatory for a more robust and formalized approach to analyze institutional change in the CE transition. Several existing conceptual frameworks explain why CE is the most effective way to go about material use (Murray et al., 2015; Lewandowski, 2016). However, there is no existing unified theory or conceptual approach on how CE can be implemented (Murray et al., 2015). Institutional analysis so far has not focused on CE. To the best of our knowledge, no theory exists that provides an insight into how organizations create new institutions in order to facilitate circular material flows. Because of the lack of existing theorization on this subject, new propositions are needed. This is of importance for both CE practitioners as well as scholars who use institutional analysis to explain the complex and interdependent functioning and change process of institutions in our society. Institutional analysis research with a sustainability focus is of particular importance (Lozano et al., 2014). Our inductive research approach therefore aims at extending institutional analysis on the topic of institutional change, as is the case when transitioning from a linear to a circular economic system.

As mentioned above, empirical cases were selected but securitizing firms and initiatives operating in the Dutch textile industry was based on two main criteria: (i) the case referred to a frontrunner in the domain of $C E$ business practices actively engaged in inter-firm collaborations; (ii) the case was supported by (publicly) available data and diverse sources of information. Therefore the selected cases represent the main business initiatives revolving around circular economy based collaborations in the Dutch textile industry. The selected cases can be clustered in two groups. The first cluster of cases consists of $\mathrm{CE}$ accelerating or intermediary organizations, namely Cradle-to-Cradle Products Innovation Institute (C2C), Circle Economy, and Turntoo. These organizations are not primarily active in the textile industry, but play a role in the acceleration of transition to a circular economy. In that sense, they focus on understanding and developing new business models and connecting actors aiming at creating circular metabolisms. In other words, these organizations are engaged in setting up new organizational forms, such as contracts, to facilitate transition into CE.

The second cluster of cases are for-profit organizations/businesses that have been experimenting and acting as frontrunners in the transition process to circular materials flows in the Dutch textile industry. Examples of these are House of Denim, Mud Jeans, and Lena Fashion Library. These companies operate and strategize 
by using different business models to create social and economic value within the wider process of transitioning into CE. Moreover they are all concerned and engaged in circular material flows related to inter-firm collaborations. The organizations selected as cases were all available for interviews and willing to provide information on their activities in creating circular material flows. Interviews with and documents from these organizations provided rich qualitative data. Firstly, interviews were conducted with the three CE accelerating organizations (C2C, Circle Economy, and Turntoo), discussing several concepts and viewpoints concerning the ways materials cycles are shaped, changing arrangements (i.e. institutional entrepreneurship), and new interdependencies and collaborations with chain partners and other stakeholders. This first cluster of data, concepts and ideas were further fine-tuned and used as input for a new set of interviews, this time with the businesses in the textile industry: Lena Fashion Library, House of Denim, Mud Jeans and Dutch aWEARness. By comparing and contrasting insights from multiple observers and empirical materials, this method of data triangulation reduced single-observer biases (Cohen and Manion, 2000). This approach resulted in different perspectives on state of the art CE practices and concepts, both seen from within the textile industry in general, as well as from the $\mathrm{CE}$ accelerating organizations.

Overall, the theory building process consisted of three conceptualization rounds. The first round was aimed at creating the initial theoretical framework in order to find a reference point to start explaining the transition towards $\mathrm{CE}$ by using an institutional analytical approach. This provided the main concepts to be used in the in-depth interviews with CE accelerating organizations and CE practitioners in the Dutch textile industry. Particular focus was placed on selecting and defining concepts to identify collaborations, and to understand their antecedents, such as the conditions in which they emerge, the type and intensity of interdependency between actors, and the main organizational elements used to arrange them. The aim was to clearly identify strategic situations in which actors negotiate solutions to manage their collaborations. The second conceptualization round took place during the data collection process; comparing findings from accelerators and practitioners. In this phase, concepts have been fine-grained, and focused on the specific organizational elements used to cope with or change the existing constraints provided by the current linear system. Based on the outcomes of this phase, the third conceptualization round took place within the research team, leading to definition of the conceptual propositions as presented in the discussion below. In this final round, the research team focused on a set of organizational elements that more clearly cope with the current system and thus still relies on existing rules, as opposed to a set of organizational elements challenging the existing rules, assuming the nature of self-enforcing mechanisms.

\section{Results}

\subsection{Institutional changes and inter-firm collaborations in circular textile material flows}

In this section the results of the empirical research are presented. As stated in the introduction, the Dutch textile industry is seen as a frontrunner in the transition to circular material flows. The cases selected for this research all deal with the transition into circular economy and involve the Dutch textile industry in diverse ways. Analysing their circular activities showed the accelerating organizations (C2C Products Innovation Institute, Circle Economy and Turntoo) as well as the textile business cases creating diverse strategic situations. Accelerating organizations (C2C Products Innovation Institute, Circle Economy and Turntoo) each support a different circular strategy. C2C Fashion Positive program is facilitating material (re-)designing, Turntoo facilitates closed looping with a product-as-service model and Circle Economy Fibersort project aims to create an infrastructure after user life. Also the textile business cases show diverse circular strategies. Lena Fashion Library and Mud Jeans have a product-as-service strategy (respectively lending and leasing garments), House of denim aim at establishing an industry standard of using post-consumer recycled (PCR) materials in new fabrics and Dutch aWEARness facilitates a whole circular value chain. For the purpose of illustrating and comparing the strategic situations of the studied cases they were positioned depending on their circular strategies in Fig. 3. This figure has been adapted from the value hill model (Achterberg et al., 2016), a circular strategy tool for businesses. Particularly Achterberg et al. (2016) suggest that circular business strategies can be grouped in four categories: circular design strategies (developing products and materials aiming at long term value retention), optimal use strategies (supporting longer and improved usage), value recovery strategies (capturing value after user life), and network organization strategies (supporting and connecting the other strategies).

The analysis of the different cases provided a number of diverse and heterogeneous strategic situations related to organizational arrangements of inter-firm collaborations in circular materials flows. Particularly, we have been able to identify typologies of strategic situations in these inter-firm collaborations and distill the main organizational elements emerged in order to negotiate solutions in these situations.

An overview of cases, aims and strategic situations is provided in Table 1. Detailed case descriptions can be found in the appendix. We have grouped these emerging organizational elements in three distinct typologies, namely organizational elements related to chain coordination mechanisms, contracting, and financial mechanisms. While contracting and financial mechanisms are organizational elements typically arising when firms were starting to engage in collaborations to manage circular material flows, chain coordination mechanisms remain important and develop during a long term collaboration to manage circular material flows.

\subsection{Chain coordination mechanisms}

An important strategic situation to set up collaborations related to circular material flows is when organizations have to define and implement coordination mechanisms at the network or value chain level. Chain coordination mechanisms can be defined as the interaction between different actors in the value chain which enable inter-firm collaborations. Chain coordination can be performed by chain actors themselves or mediated by an external actor. It is often facilitated by collaborations that include software companies or technology developers, such as for instance in the CE program or in the Dutch aWEARness case.

One of the challenges of chain coordination in circular material flows is often the lack of clarity related to the quality that can be expected from fabrics made with post-consumer materials. Oftentimes, there are misconceptions concerning quality, price, and availability of these fabrics, and suppliers and buyers fail to get aligned. Many companies operating in the textile industry are still not aware of the possibilities and quality of post-consumer fabrics (Circle Economy, 2015; House of Denim (2015)). At fabric fairs, like Premiere Vision, these fabrics are not showcased and therefore not easily accessible for many brands. Conversely, suppliers often believe there is limited, or even a lack of demand for these fabrics, since brands do not yet ask for them. For these brands and fabric suppliers, coordination is essential. CE is for example very active in creating links between buyers and suppliers of post- 


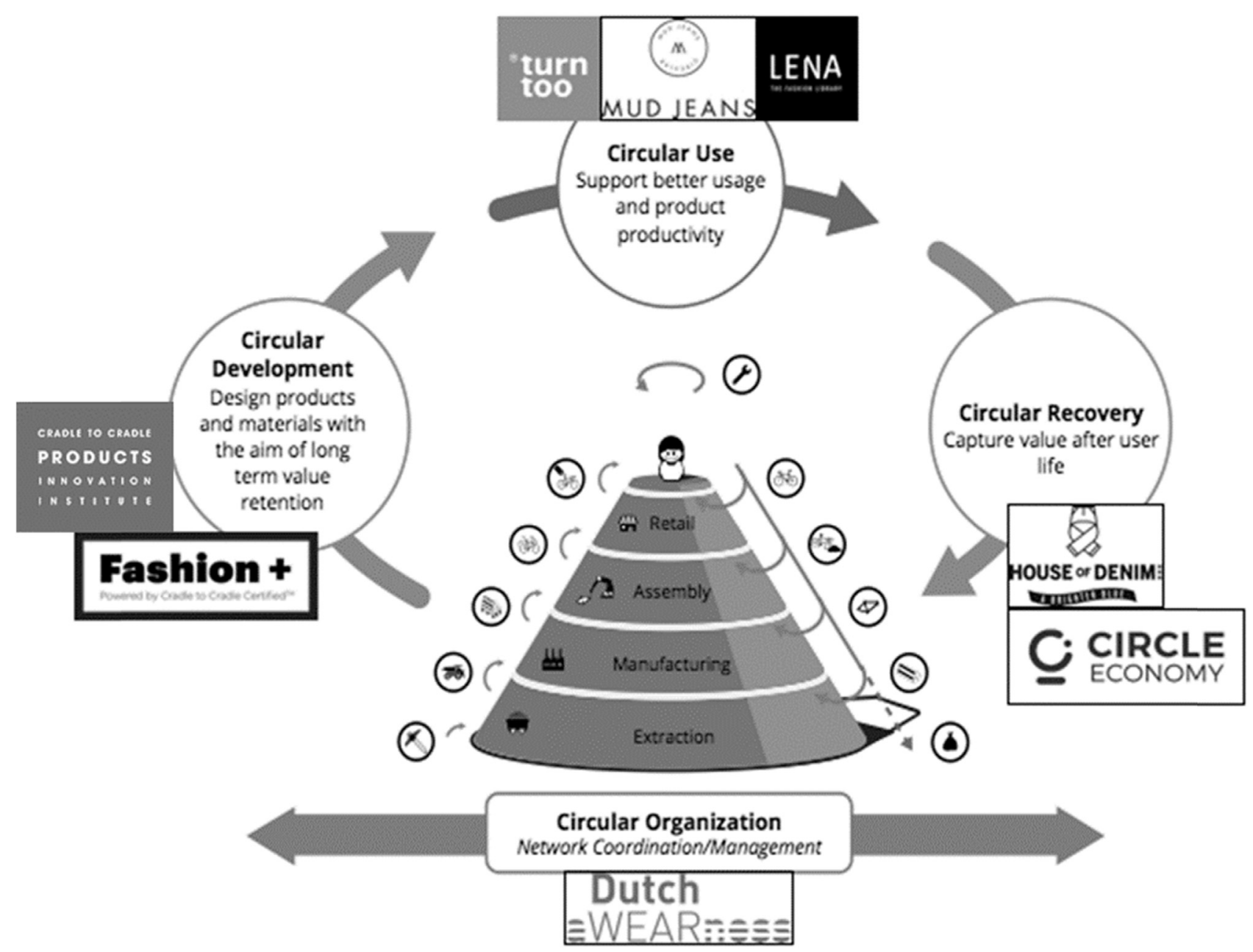

Fig. 3. Studied cases and their circular strategy. Source: adapted from Achterberg et al. (2016).

consumer fabrics (Circle Economy, 2015).

When concerning product-as-service business models, chain coordination is a more limited issue in the interaction/alignment with customers (either B2B or B2C). Turntoo for instance, links supply and demand by helping their clients to buy products in the form of services. When a certain service does not exist, Turntoo discusses with interested stakeholders to help them set up a specific, tailor-made product as a service business model. Turntoo actively looks for partners to close loops in various material flows. In doing so, Turntoo has built enough experience with choosing products and materials such that they are able to select the right products to function as a service model. These products are qualitatively suitable to be modular since they can be re-used and the materials can (generally) be up-cycled (Turntoo, 2015). It must be noted that Turntoo currently does not have clients in the textile industry. Their focus lies primarily on technological nutrient cycles whereas textiles are often biological nutrients. The reason for focusing on technological materials has been the initial interest for this cycle since these "nutrients" are often scarce and thus valuable (Turntoo, 2015). However, Turntoo is also considering expanding their focus to the textile industry, whilst also influencing companies operating in the sector, such as Mud Jeans.

In the case of Dutch aWEARness, chain coordination is part of the product as a service business model. Dutch aWEARness is the connecting link between several supply chain actors and it is the provider of garments as service. In that sense it combines the activities of going upstream in the supply chain in order to improve materials, but also going downstream to interact with its clients (B2B) directly. Mud Jeans also has both activities of going upstream in the chain, for example working with Italian factories that can use a large percentage of post-consumer textiles in new fabrics, and downstream in working directly with clients (B2C) in leasing the jeans.

\subsection{Contracting}

Arranging new contracts among partners participating in the material flows turned out to be an important strategic situation in all cases. For the CE accelerators, contracting is primarily about facilitating arrangements between "supply chain" actors. In the case of $\mathrm{C} 2 \mathrm{C}$ these arrangements are based on setting up a consortium or associational contracts (e.g. long-term multilateral partnership) with upstream chain actors to initially create improved materials and semi-fabricates to be used downstream by the fashion brands and other textile sectors. Making optimized materials more widely available requires some form of open source sharing of new production methods. As long as their specific designs and know-how are protected, fashion companies are willing to cooperate in order to improve material production processes. In the Fashion Positive project there are specific contracts with the 
Table 1

Strategic situations and organizational elements as emerged from the cases.

\begin{tabular}{|c|c|c|c|}
\hline Case & CE strategy & Aim & Strategic situations \\
\hline $\begin{array}{l}\text { Cradle to Cradle } \\
\text { Product Innovation } \\
\text { Institute }\end{array}$ & $\begin{array}{l}\text { Fashion Positive } \\
\text { Program }\end{array}$ & $\begin{array}{l}\text { To design and create Cradle to Cradle } \\
\text { materials/fabrics for enabling } \\
\text { circular textile flows }\end{array}$ & $\begin{array}{l}\text { - Dealing with sequential dependency between chain partners and } \\
\text { incentive alignment (upstream) (chain coordination) } \\
\text { - Facilitating pre-competitive material improvement processes (con- } \\
\text { tracting \& chain coordination) } \\
\text { - Pooling know-how and technologies (contracting and financial } \\
\text { mechanisms) }\end{array}$ \\
\hline Circle Economy & $\begin{array}{l}\text { Textile Sorting } \\
\text { Project }\end{array}$ & $\begin{array}{l}\text { To develop and manage a post-consumer } \\
\text { textile sorting platform }\end{array}$ & $\begin{array}{l}\text { - Developing and coordinating chain relations between collection, } \\
\text { scanning technology \& software for post-consumer textile infra- } \\
\text { structure and sorting machine (contracting \& chain coordination) } \\
\text { - CO-investing in a post-consumer textile sorting machine (Fibersort) } \\
\text { (financial mechanisms) }\end{array}$ \\
\hline Turntoo & Product-as-service & $\begin{array}{l}\text { To facilitate adoption and diffusion of } \\
\text { product-as-service business } \\
\text { models to manage products and materials }\end{array}$ & $\begin{array}{l}\text { - Managing products in use by customers (service contracting) } \\
\text { - Share knowledge and information (contracting and financial } \\
\text { mechanisms) }\end{array}$ \\
\hline House of Denim & Denim Lab & $\begin{array}{l}\text { To set an industry wide standard for using } \\
\text { non-re-wearable textiles (Post-consumer } \\
\text { CR) in new fabrics }\end{array}$ & $\begin{array}{l}\text { - Developing and coordinating chain relations (upstream) (chain } \\
\text { coordination) } \\
\text { - Joint investments in upcycling technology development (contracting) }\end{array}$ \\
\hline Mud Jeans & Lease a jeans & $\begin{array}{l}\text { To facilitate adoption and diffusion of } \\
\text { 'lease a jeans' concept (product-as-service } \\
\text { business model) }\end{array}$ & $\begin{array}{l}\text { - Developing and coordinating chain relations (downstream) (chain } \\
\text { coordination) } \\
\text { - Managing garments in use by customers (service contracting) }\end{array}$ \\
\hline Lena Fashion Library & Fashion library & $\begin{array}{l}\text { To facilitate adoption and diffusion of } \\
\text { 'fashion library' concept } \\
\text { (product-as-service business } \\
\text { model) }\end{array}$ & $\begin{array}{l}\text { - Developing and coordinating chain relations (downstream) (chain } \\
\text { coordination) } \\
\text { - Managing garments in use by customers (service contracting) }\end{array}$ \\
\hline Dutch aWEARness & $\begin{array}{l}\text { Leasing corporate } \\
\text { garments }\end{array}$ & $\begin{array}{l}\text { To facilitate adoption and diffusion of } \\
\text { leasing corporate wear } \\
\text { (product-as-service business model) and } \\
\text { align incentives of value chain partners }\end{array}$ & $\begin{array}{l}\text { - Managing garments in use by customers (service contracting) } \\
\text { - Developing and coordinating chain relations (up- and downstream) } \\
\text { (chain coordination) }\end{array}$ \\
\hline
\end{tabular}

Source: own elaboration on data from case studies.

fashion companies that deal with large collections of garments and investments of millions of euros. These contracts are the basis for working together in pilot projects in order to create products that can be entirely up-cycled after use. In order to protect the confidential information, like business processes, formulas, strategies, financial information, et cetera, existing non-disclosure contracts are a core part of the overall agreements. These contracts lack specific output targets since it is often unclear what outputs can be expected (Cradle to Cradle, 2015). This way, manufacturing companies are stimulated in to transition and guided in this effort more easily as compared to use of more rigid contracts based on expected outputs and penalties. The starting point is to optimize one product or one collection followed by up-scaling the whole collection. The higher the quality of fabrics and other materials that are optimized, the larger the amount of garments that can be used for up-cycling into new garments. The manager of Cradle to Cradle called this process the 'growing material library' (Cradle to Cradle, 2015). This approach allows the Fashion Positive project to use existing nondisclosure based contracts to protect intellectual property and other brand specific resources, while still creating room for collaboration among partners. Moreover, targets in the collaboration are loosely set as to allow for emerging opportunities.Whereas C2C moves upstream in the supply chain, the Circle Economy's Textile Sorting project moves downstream in the supply chain. The contractual approach used in this project is comparable to Fashion Positive's, since existing contracts to manage sorting of materials are used simultaneously by all supply chain partners to manage the flows of material and therefore the collaboration relationships. Contracts are formalized in order to improve the coordination of sorting post-consumer textiles, and to increase the capacity to achieve a financially viable business model for all chain actors (e.g. collectors, scanning and sorting technology, chemically recycling cotton-polyester blends, et cetera).

Turntoo is primarily concerned with creating products as service contracts. Closing the loop for Turntoo starts with the current situation of the client company. When Turntoo starts a project in cooperation with a client, for example for producing or buying products on a service basis, or for creating a whole service based unit, they start by sketching the strategic situation in which the loop has to be closed, and with whom. Subsequently they analyze how the business model should function, what the consequences are when a service model is created with that product, what the contract should look like, who is the target market, et cetera. A pilot project is set up in which the circular cycle/loop is tested for the first time. During and after the pilot, both processes as well as products are fine-tuned in order to improve the circular process for the generation of products in the next cycle/loop (Turntoo, 2015). Turntoo is action-focused and uses pilots to "learn by doing". Contracts used to manage the pilots are always loosely set up. For example, a client company can always stop the project or put it on hold if there is a budget problem or when focus has to be shifted (Turntoo, 2015).

For the textile business, the type of contracts used depends on the business model adopted in the specific collaboration. House of Denim uses for example, business-to-business (B2B) contracts, since their partners in the project are other companies. Contracts are set to facilitate collaboration, manage property rights issues and joint learning, and foster the possibilities of using post-consumer textiles in new fabrics. Lena Fashion Library and Mud Jeans have a similar model in the sense that they offer garments as a service (product-as-service). However, they have contracts with their customers (B2C) in the form of a subscription paid as a monthly fee.

Finally, Dutch aWEARness is a frontrunner when it comes to novel contracts and arrangements for collaboration. Since they have to manage technology development and materials at supply chain level they have designed a brand new "leasing" contract for up-cyclable garments. They add to the leasing contract a "product as service" approach, since business partners using the garments are offered the opportunity to access a "repair service" during the contractual period. The Dutch aWEARness case shows that 
collaboration can result in a chain wide system of circular material flows and provides the incentives to improve company activities aiming at circular material cycles. However, the project is constrained by the rigidity of the actual juridical system which is limiting the possibilities to create co-ownership when it comes to materials to be used by several partners in the chain. The issue is concerned to locating ownership of products and materials in the chain instead to a single company, which is requiring Dutch aWEARness to manage it through a combination of formal and informal contracting.

\subsection{Financial mechanisms}

Two main issues arise from the case studies that concern financial mechanisms. The first issue is the need for facilitating joint investment to develop new technologies, proof of concept, and/or scaling up technologies (for instance sorting and fiberization $^{6}$ machines) (Circle Economy, 2015). Investments in specific upcycling technologies like the fiber-sort machine ${ }^{7}$ may seem as a risky investment to banks since they lack the specific knowledge about return on investment (Circle Economy, 2015). C2C fund and the investments of the different stakeholders collaborating on the circular textiles project are examples of stakeholders in the textile supply chain that co-finance these projects for up-cycling technologies (Cradle to Cradle, 2015; Circle Economy, 2015). For developing new technologies, government funding can be attracted, as shown in the Dutch aWEARness case.

The second issue concerns financing products as service business models. Small-scale entrepreneurs with product-as-service business models do not have extensive financial resources. A problem arises from the way financial institutions assess business plans in order to grant funding: when businesses, for instance, apply for a loan to fund a project, the bank often uses a checklist to assess whether the project is likely to be successful. This checklist however, is based on successful performances and features based on standard linear approaches. This means that lending organizations are looking at ownership of materials in order to consider them as collateral assets. However, if businesses sell a product as a service, the assets (e.g. products that are leased to consumers) stay on the balance sheet of the company, resulting in a growing balance sheet with a slowly increasing cash flow instead of immediate sales. Investments are needed to acquire the assets, but because assets are not sold (leading to immediate cash for acquiring new assets) the business needs a substantially increased amount of working capital to continue acquiring new assets (Working Group FinanCE, 2016). This is problematic because these business models/projects do not receive the required investments. An example of the mismatch between new business models and financing models of banks is Lena Fashion Library (Circle Economy, 2015; Lena the Fashion Library, 2015). Lena has a certain amount of members and is assured of a monthly income, cash flow. However, since the garments are not necessarily bought or sold, banks often decline the request for investments. Decision factors behind financing models are based on linear business models. This creates severe barriers for start-ups and small enterprises that try to adopt and scale up a circular business model. Up-scaling problems can be solved when constructing financing models based on cash flows rather than assets (Circle Economy, 2015).

A promising way to share risks and rewards more fairly in circular materials flows is to apply a so-called "dynamic earning model", which also motivates companies to be more innovative

\footnotetext{
${ }^{6}$ Fiberization is the process of breaking up fabrics into fibers.

7 The sorting machine created by Circle Economy's textile sorting project.
}

(Turntoo, 2015). This model can be understood as an agreement between two or more parties concerning sharing revenues (or 'rewards') and risks. When multiple companies structure a dynamic earning model they try to manage asymmetric distribution of risks and revenues along the chain or system. In circular material flows it can be often the case that risks have to be taken by company A (for instance a service or technology provider) whereas revenue increases will take place at company B (for instance due to modular design and remanufacturing activities). Since the agreement is based on sharing, any increase in revenues will benefit all parties involved. Vice versa, if there is a problem in the chain that pressures revenue streams, or increases risks, parties will be inclined to collaborate to solve the issue. These dynamic earning models enable incentive alignment and increase trust and collaboration. Sharing risks and rewards can speed up the transition to circular material cycles since successful improvements to products and processes will benefit all chain actors, resulting in high levels of trust, reciprocal behavior and continuous innovation (Turntoo, 2015; Working Group FinanCE, 2016). Current bottlenecks at the moment are the juridical difficulties concerning sharing risks and rewards of new financial models. This is also shown in the Dutch aWEARness case in which the juridical issues arose when trying to define and allocate the ownership of products and materials collectively, at the chain level instead of the single company level.

\section{Conceptualization and theory building: two pathways of institutional change in circular collaborations}

Consistently with the inductive nature of our approach, in this paragraph we first present how, through an in-depth analysis of the different cases and the specific strategic situations, two pathways have been distinguished in the way actors design and set new rules when collaborating in circular material flows. As presented in Table 2, a dichotomy has been found between what we have defined as status quo arrangement (SQ) pathway and a product-asservice arrangement (PAS) pathway. While the SQ pathway relies on existing general rules of the linear economy, and thus deals with transition into a circular economy through coping with the existing institutional setting, the PAS pathway is characterized by rules that do not rely on existing institutions and assume the connotation of self-enforcing constraints, applied and implemented at the interorganizational level.

SQ focuses on optimizing up-cycling technologies and infrastructure - for example as promoted in projects run by $\mathrm{C} 2 \mathrm{C}$, Circle Economy, and the House of Denim - using existing rules and aligning them with the current way in which value chains are organized. SQ emerges prevalently in the contractual and chain coordination dynamics of collaborations dealing with collection of post-consumer textiles. This is arranged by making use of existing infrastructures, such as for example using the network of containers provided by municipalities, in a manner similar to how glass and paper are collected.

PAS pathway, as promoted by Turntoo, Lena Fashion Library, Mud Jeans and Dutch aWEARness, instead focuses on providing products as service contracts. They are self-enforcing mechanisms since they do not rely on existing rules and value chain structures, such as, for example, in terms of ownership or distribution of risks and incentives. By providing products as service contracts, like for instance a lease contract, ownership of the product remains at the producer or leasing company while customers pay for using the product for a certain period. When the product returns to the company after use, cascading activities, like leasing again, refurbishing or harvesting materials, take place. The two pathways are characterized by different rules when it comes to arrange interfirm collaborations of circular materials flows. Table 2 presents 
Table 2

Rules emerging in strategic situations connected to SQ and PAS pathways.

\begin{tabular}{|c|c|c|}
\hline $\begin{array}{l}\text { Organizational elements } \\
\text { of inter-firm } \\
\text { collaboration }\end{array}$ & Status quo (SQ) & Product-as-service (PAS) \\
\hline \multirow[t]{2}{*}{$\begin{array}{l}\text { Chain } \\
\text { coordination mechanisms }\end{array}$} & Managing up-cycled fabrics & PAS and Cascading \\
\hline & $\begin{array}{l}\text { Upstream: Develop C2C materials for } \\
\text { up-cycling purposes } \\
\text { Downstream: Involve consumers in the process of } \\
\text { collecting post-consumer textiles } \\
\text { New value chain: Collection, sorting, scanning- } \\
\text { and sorting technology businesses. } \\
\text { New product-market combinations: } \\
\text { Link supply- and demand } \\
\text { for fabrics with percentage up-cycled fibers }\end{array}$ & $\begin{array}{l}\text { Upstream: Include dying, weaving, yarn, polyester } \\
\text { businesses in a collaborative chain } \\
\text { Downstream: Consumers become users of the service } \\
\text { New value chain: Remote monitoring of whereabouts } \\
\text { garments, ownership of garments remains } \\
\text { at producer (or other location in value chain) } \\
\text { New product-market combinations: Product-as- } \\
\text { service (lease) instead of product sales, stimulation } \\
\text { of PAS and collaborate in cascading activities }\end{array}$ \\
\hline \multirow[t]{2}{*}{ Contracting } & Relational long-term contracts & Relational service contracts \\
\hline & Contracts for pilot projects for up-cycling materials & Creating contracts for PAS, contracts with cascading partners \\
\hline \multirow[t]{2}{*}{ Financial mechanisms } & Standard financing & New financing models \\
\hline & $\begin{array}{l}\text { Investments in technologies for optimizing materials and } \\
\text { up-cycling post-consumer materials }\end{array}$ & Cash flow based financing, dynamic earning models \\
\hline
\end{tabular}

Source: own elaboration on case studies

these rules as related to the specific strategic situations in which they have emerged.

As proposed, we looked at chain coordination mechanisms as organizational elements enabling firms to arrange collaborations in circular materials flows. Multiple chain coordination mechanisms apply for both SQ and PAS pathways. In the case of SQ pathway, we observe that chain coordination mechanisms are mainly related to the usage and management of up-cycled fabrics through rearranging existing organizational arrangements. Particularly chain coordination mechanisms deal with creating "quality standards" to be shared and used to reverse logistics and closing loops of materials, on the one hand, and to further foster technology developments facilitating relationships between buyers and suppliers, on the other hand. These chain coordination mechanisms revolve both when oriented to facilitate upstream coordination, such as in the case of C2C's Fashion Positive programs, or House of Denim is upstream chain directing, as well as downstream in the chain, for example with consumers, as in the case of Circle Economy's project.

Proposition 1. Chain coordination mechanisms for SQ focus on collaboration for up-cycling materials by introducing new industry (quality) standards, and improving the post-consumer process by facilitating buyers-suppliers relationships and co-investments.

In PAS pathways, chain coordination mechanisms are oriented to develop long term and more interdependent collaborations, turning flows of materials between buyers and suppliers in functional metabolisms. In PAS arrangements, partners are also aiming at retaining control over products and materials by selling the service of the product. As such, PAS chain coordination is oriented to include all users of materials in the collaborative cycle (metabolism), including the "final consumers". In so doing, chain coordination mechanisms revolve around the idea to change ownership of materials and associated service and move it from a single supplier to the inter-firm collaborations. Coordination is meant to be inclusive, as metabolisms are open to new partners/users.

Proposition 2. Chain coordination mechanisms for PAS aim at long term development of chain collaborations, in order to keep garments and materials cycling through the chain, while supporting the growth of the demand for PAS garments. PAS include upstream and downstream partners in order to fully close the loop by bringing the ends together. By including consumers in the loop as 'users', there is a new vital role for these users in closing material loops.

Contracting is another organizational element in which differences among the two pathways emerge. The legally binding aspect of contracts ensures stakeholders that contractual agreements will be kept. Although the form of the contract is used as an arrangement to create circular material flows, the content can be different from the content in a contract for linear economic transactions. Whereas linear economic transaction contracts consist of (a variation on) the agreement (stakeholder A delivers $X$ for stakeholder B delivering $\mathrm{Y}$ in return), contracts for transitioning to circular material flows are often set up in a less explicit manner. Since arrangements to develop circular material flows consist of activities like optimizing materials, re-designing products, creating cascading activities and collaboration between different stakeholders which are poorly codified by the existing regulations and industry standards, contracts are aimed at creating flexibility. For example to foster group problem solving, inter-firm authorities, and various forms and degrees of sharing property and decision rights. Thus contractual arrangements often assume an informal and relational connotation, in both SQ and PAS pathways. They are primarily oriented to bond partners; create mutual trust, collaboration, and room for new processes and structures that may evolve during the collaborative project. For this reason, these contracts do not explicitly state expected outputs, but merely the goal of improving materials and processes for the transition to circular material flows. Relational contracting is a way of contracting in which gaps in the agreement are overcome by the commitment, reputation, and trustworthiness of the stakeholders (Baker et al., 2002). These contracts are effective when stakeholders collaborate for a longer period of time and when the goals are modified over time as a result of unfolding events (Slangen et al., 2008). Relational contracting is a tool for aligning stakeholder goals and creating collaborative projects for the transition to circular material flows. While both SQ and PAS contracts have elements of relational contracting, contracts used in SQ pathways are mostly about longterm collaboration for optimizing materials and technologies mainly at a pre-competitive stage. Differently, PAS contracts are about collaboration for cascading activities and creating service contracts for multiple partners (B2B and B2C). The complementary nature of PAS collaboration, such as the different cascading 
activities fulfilled by a different stakeholder, is more likely to increase the degree of sharing property and decision rights on materials, and facilitates collective action and cooperative behaviours, since a cluster or group of companies is formed in which risks and gains are ideally distributed over multiple collaborating stakeholders.

Proposition 3. Contracts in both SQ and PAS pathways have a relational connotation. In $S Q$ relational contracts focus on long term collaboration for optimizing materials and technologies at a precompetitive stage. In PAS contracts, focus is placed on sharing property and decision rights on materials, to facilitate take-back systems between multiple actors (instead of bilateral agreements), aiming at aligning incentives in creating circular material flows.

Financial mechanisms are organizational elements which are specifically important for PAS. They are a way for firms to work together in creating circular material flows that allow for risk spreading and stimulate innovation (Turntoo, 2015). Providing PAS in collaboration by using dynamic earning models provides an incentive for improving materials and products since this benefits all stakeholders. Since it is legally impossible to construct dynamic earning models, a change in legislation will be necessary eventually. In order to push for legislation to be altered, codes of conduct and procedures have to be defined and shared at the business level (Turntoo, 2015) in order to implement these types of models. Currently, the development of PAS business models is limited by the investment criteria used by financial institutions, which are mainly based on assessing ownership on assets. This approach is not suitable for financing PAS models in which ownership is shared and often ill or informally defined. Circular financing based on cash flow can be seen as a more appropriate financing model, since providing PAS in lease contracts generates a continuous cash flow (Circle Economy, 2015). CE accelerating organizations may play an important role as broker between banks and firms, creating PAS business models with the goal of developing circular financing models. This is an important barrier to overcome for accelerating the transition to circular material flows in PAS pathway. For SQ new financial mechanisms are less important. Since SQ arrangements concern investments in technology and machinery, asset based financing can be more easily applied (Cradle to Cradle, 2015).

Proposition 4. Circular financing mechanisms, like cash-flow-based financing and dynamic earning models, are needed for financing PAS arrangements whereas SQ arrangements can be financed with current financing mechanisms.

\section{Discussion and concluding remarks}

Using information and data from cases of inter-firm collaborations engaged in transition to circular material flows resulted in discovering a dichotomy between SQ and PAS pathways. Chain coordination, contracting, and financial mechanisms, have been identified as key elements for stimulating the emergence of new organizational elements of inter-firm collaborations and eventually new rules for managing circular economy material flows and metabolisms. Both SQ and PAS arrangements, while created by firms to manage collaborations and exchanges can have consequences at multiple institutional levels. Whereas SQ arrangements may have implications at the level of formal rules, for example in creating a new industry standard for regulating use of up-cycled fabrics, PAS arrangements may have wider implications, by for example reshaping ownership in service contracts and creating cascading supply chain activities. Both SQ and PAS arrangements aim at creating new rules for managing circular material flows, albeit through different pathways.
The difference between SQ and PAS pathways holds important implications for stakeholders. Since it is questionable whether SQ arrangements can lead to circular materials cycles, stakeholders have to decide whether this set of arrangements, aiming at raising industry standards for up-cycling post-consumer textiles in new garments, is a desirable path to follow. Although it may be worthwhile to collaborate with chain partners in order to address the technological challenges of up-cycling materials, stakeholders have to realize that collaborating in circular material flows can provide more opportunities than just achieving new technological solutions (Murray et al., 2015). Therefore, supply chain collaboration should not only be used to improve up-cycling of fibers, for example through technological improvements, but also to think about new configurations of supply chains, as is the case for PAS arrangements. PAS as SQ arrangements rely on and need technological solutions to tackle the challenges of up-cycling materials (Preston, 2012) however they also seem to create the conditions to benefit from changes at multiple institutional levels. For example, providing products as service contracts, they facilitate the shift of responsibility for materials, property rights, and the cultural aspect of ownership. Moving ownership to the supply chain, to for instance the manufacturer or service provider, will result in increased responsibility for materials and will create an incentive for improving quality of products, including their environmental performance. Increased quality and extended life cycle of products co-owned by supply chain partners will generate value by keeping products cycling longer before cascading, and cascading longer before remanufacturing or recycling them in order to harvest the (raw) materials for creating new products. This is expected to generate positive socio-environmental impacts at a system level as well. It is a legitimate question whether the benefits of PAS business models, like Mud Jeans, Lena Fashion Library, and Dutch aWEARness, will convince customers to participate in PAS arrangements. If a critical number of PAS arrangements become available and are embraced by customers, it will have disruptive effects at the level of the supply chain structure. At supply chain level, the long-term effects of PAS and cascading can be the transition from linear supply chains to circular supply eco-systems in which products, parts of products, and materials can circulate in multiple sectors and industries. This may imply the vanishing of barriers between industries as we know them today, and the clustering of cascading activities around specific materials or activities instead of a specific industry. To give an example, clustering of cascading activities around wood can occur instead of the separate supply chains for the building industry, furniture industry, paper industry, and other industries that use wood. In other words, the focus of firms will shift from relative positioning in the supply chain (connections with chain partners) to the relative positioning in material cycles. Therefore it is likely to expect that a robust development of PAS may generate large scale effects, such as the removal of barriers among industries and society towards the circular economy.

A question still arising with the potential diffusion of PAS arrangements relates to the effects on ownership moving from firm to supply chain level. At this stage of the transition it is unclear where ownership could be located, since this conceptual model only shows the movement of materials, and not of ownership. Since materials and added value in products are the focal point of a PAS system, ownership of materials implies a power shift in the circular metabolism/chain. Stakeholders should keep this in mind and should find ways to introduce institutional mechanisms in order to circumvent concentrations of large amounts of materials being owned by one single stakeholder. Shared ownership models and/or collaboration between multiple small or medium sized material owners in networks can be a more balanced solution rather than accommodating large amounts of materials at a few large 
stakeholders, such as a material bank or multi-national. More small and medium sized stakeholders, as opposed to a few large stakeholders, could be a solution to create fair competition and fair prices for consumers. Finally, issues to overcome are how to cope with obstructing legislation and the lack of adequate financing models. If stakeholders can create arrangements that circumvent these barriers they may become examples for other stakeholders to transition to PAS arrangements. Turntoo (2015) mentioned an example of such an arrangement by formulating contracts in such a way that limiting legislation is omitted. Moreover, more PAS arrangements may have bottom up effects on the formal institutional level, resulting in alteration and creation of formal rules that are in line with PAS business models.

This research is also limited in some aspects. Firstly, the main limitation of this research lies in the pioneering nature of this study. Due to a lack of prior knowledge on transition mechanisms for $\mathrm{CE}$, an institutional analysis perspective was selected in order to create new concepts for transition mechanisms in the form of arrangements created by firms. For the aim of this inductive research, multiple cases in the Dutch textile industry were studied which led to the development of new concepts about the ways firms shape institutions for the transition towards circular material flows. Triangulation was used to introduce concepts from previous cases in interviews with new cases. However, the concept of CE itself is still new and under development. This hindered the triangulation process since respondents had different ideas about to what extent circular material was desired. At times, data appeared in a more anecdotal way than being aimed at the triangulation method. This also resulted in two clearly different sets (pathways) of arrangements, one focusing on optimizing materials and raising industry standards (SQ) and another focusing on cascading and shifting ownership (PAS). Moreover, it can be questioned whether the concept for cascading in circular supply eco-systems can be applied to other sectors and countries. Based on the reasoning that PAS will provide an incentive to take responsibility for material (re)use and opportunities for new PAS arrangements, it is likely that the mechanisms of cascading and circular supply ecosystems can emerge in a similar pattern as conceptualized in this research. However, the inductive nature of this research leaves this question for future deductive research.

\section{Annex I Description of the case studies}

\section{A. Cluster I: Circular economy accelerating organizations}

\section{Case 1: Cradle to Cradle Products Innovation Institute}

Cradle to Cradle Products Innovation Institute (from now on $\mathrm{C} 2 \mathrm{C}$ ) is a non-profit organization and certification program that helps firms to optimize their materials and the design of their products in order to obtain the certificate Cradle to Cradle Certified $^{\mathrm{TM}}$. C2C has implemented a business model in which certification is seen as a process and as a way to provide a service to companies interested in transitioning into $\mathrm{CE}$. As such $\mathrm{C} 2 \mathrm{C}$ is not only interested in certifying but also engaging with these companies; facilitating the adoption and diffusion of standards in line with CE principles. The highest standard, a gold-certification level, indicates that products in the textile industry can be up-cycled to new fashion items. No toxic substances are used and no materials from the biological and technological cycle are mixed (Cradle to Cradle, 2015). C2C considers blends of materials from the biological and technological cycle as the main bottleneck for the transition towards CE. It is very complex or even impossible to separate blended materials in order to up-cycle them into new fabrics. These blended materials are being down-cycled into products like cleaning towels and lining for the back of cars, or in the worst case are landfilled or incinerated. In order to optimize materials and designs to create the necessary material quality for up-cycling, together with brands, $\mathrm{C} 2 \mathrm{C}$ moves back to the supply chain. Not only the finished product needs optimization, also the yarn, colorings, buttons et cetera need to comply with C2C certification standards. Moving back in to the textile supply chain is necessary because this often brings forth companies in Asian countries where materials are mixed and pollutants are used that are not allowed in Europe and the US. In order to improve these processes, these spots in the supply chain have to become visible. In the Fashion Positive Initiative, C2C, together with well-known brands like Stella McCartney, G-star, and Trigema (see fashionpositive.org for the full list), try to raise their material standards to a gold-certification level in order to create fabrics and other materials that can be up-cycled after use. One of the partners in the Fashion Positive initiative is Circle Economy (Cradle to Cradle, 2015).

Fashion Positive Program. C2C states that their Fashion Positive initiative is in a 'leadership phase'. Together with nine renowned fashion companies, they are working together to show their customers and the rest of the industry that it is possible to create $\mathrm{C} 2 \mathrm{C}$ materials and circular textile flows. When these materials become available on a large scale, the aim is to expand these practices industry wide (Cradle to Cradle, 2015). Companies in the textile industry are currently getting ready to scale up the reuse of materials for new fabrics. Most of the large textile producers are situated in Asia. These factories produce for many different brands and they are not prepared to change their production processes if only one brand asks for different materials. Collaboration between brands is necessary to create enough pressure to convince material providers to change their materials. Brands, collectively asking for optimized materials, create an incentive for the producers to optimize their materials. Despite the competitive nature of the fashion industry, brands have to work together to create leverage for the transition towards a circular textile industry (Cradle to Cradle, 2015).

Due to the competitive nature of the fashion industry collaboration is very limited, and primarily takes place in the holding ${ }^{8}$ that brands are part of (Cradle to Cradle, 2015). Since a collective effort from textile brands was lacking, $\mathrm{C} 2 \mathrm{C}$ took the initiative to set up the Fashion Positive program in collaboration with multiple textile brands. The project aims at realizing one gold standard product or collection for each brand in the consortium. Due to the scarce availability of optimized materials in this developing phase, it is impossible to change the whole collection of a brand at once. "Currently there is no producer and no brand that can deliver that kind of material, that is what we are working on at the moment" (Cradle to Cradle, 2015). It will take a substantial amount of time before using optimized materials can become a common practice or industry standard.

Fashion Positive started with collective action and pressure from fashion brands to incentivize a yarn producer to optimize its yarn for up-cycling after user life. Working with C2C expertise and supported by the $\mathrm{C} 2 \mathrm{C}$ revolving fund, the yarn producer succeeded in optimizing the yarn in several colors. After the project is realized the yarn producer is able to sell the optimized yarn to different fashion companies, as well as being able to sell the optimized yarn on a greater scale now. This indicates that in order to realize materials being optimized, the transition to material reuse consists of a process of collaborative engagement at the supply chain level. Moreover, the revolving fund enables necessary investments in new technology, which can be repaid to $\mathrm{C} 2 \mathrm{C}$ when scaling up the

\footnotetext{
${ }^{8}$ A holding refers to a company that does not produce goods or services itself; rather, its purpose is to own shares of other companies to form a corporate group.
} 
production and sale of optimized yarn. This means several actors in the textile industry are working together in the Fashion Positive program targeting factories upstream in the supply chain, where fabrics and half-fabricates are made (i.e. buttons, yarn, et cetera). By using their collective bargaining power and the $\mathrm{C} 2 \mathrm{C}$ revolving fund, upstream factories can be convinced to invest in altering their manufacturing process in order to create a button, yarn, or fabric complying with the cradle to cradle certification criteria. After investments are made and product or half-fabricates' traits have been improved, pressure is directed upwards in the chain, convincing fashion brands and other textile-dependent industries to use the improved materials in their products. This exemplifies the concept of inter-firm collaboration that is essential for facilitating the transition. In other words, the process of optimizing materials consists of both top-down and bottom-up processes in the textile supply chain (Cradle to Cradle, 2015). This also indicates a prevailing "transactional approach" in the way fashion firms have managed to collaborate in projects of circular material flows.

\section{Case 2: Circle Economy}

Circle Economy is a non-profit organization in the form of a cooperative platform and chain-director. Their activities are two-fold; on the one hand they focus on research and analysis of the circular economy, that is, to collect data and visualize the situation in order to create awareness and provide insight in the movement towards CE. On the other hand, they develop strategies to undertake action and are actively involved in implementing those strategies. As an accelerator organization, Circle Economy works together with businesses in workshops and long-run programs in order to shape organizational forms as both formal and informal collaborations between chain-actors and other stakeholders that are used to overcome linear reality.

Circle Economy develops tools to enable businesses to gain insight in and identify opportunities for increasing circularity (the Circle Assessment and Circle Portfolio). For the textile sector, 'Circle Market' was created as a marketplace for the recovery, reuse and re-sale of textile materials (www.circle-economy.com). In their 'Circular Textiles Program', Circle Economy “aims to establish a process that ensures the recovery and up-cycling of textiles in a closed loop" (www.circle-economy.com). The aim is to break through the barriers against scaling up the use of post-consumer textiles in the textile industry. Part of the broader circular textiles program, the 'Textile Sorting Project', is a collaborative consortium that aims to develop a commercially feasible sorting technology called 'Fibersort' that is able to detect fiber composition of post-consumer textiles (Circle Economy, 2015).

Textile Sorting Project. The textile sorting project was initiated by Wieland Textiles and Circle Economy, and is a joint effort with Valvan Baling Systems, Methrohm, Worn Again, and ReShare (In the Netherlands also known as 'Leger des Heils'). In this consortium, Valvan Baling Systems is responsible for building a postconsumer textile sorting machine called 'Fibersort', Methrohm for developing scanning technology, ReShare is the collection company, Wieland Textiles is the sorting company, Worn Again the expert and market developer, and Circle Economy is the chain director and project manager (Circle Economy, 2015). Worn Again, based in the UK and currently developing a technology for chemically recycling cotton-polyester blends, joined the consortium because they could foresee the need for feedstock as input for a factory to be built in the near future. At this moment, it is still difficult to sort feedstock into what is usable and what is not; a problem that this machine could resolve. Worn Again is aware that their business model cannot function if there is no infrastructure for collecting and processing old garments. The system of the reverse-logistics; sorting, possibly a material library for postconsumer materials, processing into new materials and the demand for those materials is absent at the moment. The companies that work together in the textile sorting project understand that they have to co-operate with new stakeholders to create this infrastructure (Circle Economy, 2015). ReShare collects old garments and its business model is related to practices to throw old garments in containers, including non-re-wearable textiles. ReShare needs a way to valorize these materials with up-cycling technology and infrastructure, while at the moment, collecting these non-re-wearable textiles is costly instead of profitable due to the negative value of textiles that cannot be sold to second hand markets. Here, the Textile Sorting Project exposes a problem caused by the current linear functioning of the textile industry. The problem of costs for collecting non-re-wearable textiles has to be dealt with in order to create a profitable business case. Smits (Circle Economy, 2015) calls this problem a 'chain deficit'. One solution could be government subsidizing (Circle Economy, 2015). Worn Again and other companies like Ionica, Renew Cell, Saxion, Evernew, and Teijin are all developing textile-recycling technologies. All these stakeholders will need the Fibersort technology to handle large volumes of post-consumer textiles because it is too expensive and time consuming to sort by hand. Moreover, because labels on garments often do not correctly reflect the substances, this technology can function as a quality control system. Circle Economy states that if these various technologies - i.e. the sorting and the recycling technologies - can be commercialized, this could be the tipping point in scaling up the processing of post-consumer textiles and creating circular material flows in the textile industry (Circle Economy, 2015).

This case again shows the importance of collaboration for transitioning to a circular textile industry. Where C2C focused on improving materials upstream in the chain, Circle Economy is concerned with post-consumer textiles, all the way downstream in the chain.

\section{Case 3: Turntoo}

Turntoo, a social enterprise, introduced the concept 'product-asservice'. The vision of Turntoo is to treat products as 'storerooms' for re-usable resources. The ownership of products remains with the producer and consumers only pay for the service of using a product, often in the form of a lease contract (www.turntoo.com, 2015). After the use-period the product returns to the company that can either sell the service again, refurbish it or re-cycle the materials, depending on the situation.

Turntoo has changed its strategy since their start in 2010 after starting out as a platform and intermediary between producers or suppliers and consumers. Originally, their focus was material knowledge, but Turntoo soon realized that this knowledge is already available at the companies they work with. Moreover, by taking a key position in trying to create a circular chain, they diminished the incentive for their clients to actively change. Turntoo changed its strategy and shifted focus towards developing creative business models that allow companies to either make their products available as a service, or help clients that want to use products by service contract to find companies that want to provide these services (Turntoo, 2015). In so doing they are continuously 'experimenting' and prototyping new contracts and other organizational forms which also work as rule-setting activities for the entire CE sector/movement. By facilitating usage of new service contracts, they create and appropriate social and economic value.

Note that Turntoo, unlike the other CE accelerating organizations, is a for-profit company. They generate revenue by developing creative business models and providing consultancy on establishing circular processes, specifically product-as-service. Although 
Turntoo does not have a specific textile program, like C2C and Circle Economy do, their concept of product-as-service has had substantial implications for new organizational forms and plays an important role in the transition to circular material flows. This will also become clear in the cases on textile businesses.

\section{B. Cluster II: Dutch textile businesses}

\section{Case 4: House of Denim}

House of Denim is a 'denim lab' that recently opened its doors in Amsterdam. House of Denim aims at setting an industry wide standard of using a small percentage (around 3\%) of non-rewearable textiles (which they call PCR, standing for PostConsumer Recycled) in all newly produced fabrics. The lab, set up in a popular area of Amsterdam, showcases all the machines that are also used in large factories, and was built with an investment of their Turkish manufacturer to show their stakeholders the possibilities of quality denim fabrics that are made with a percentage of non-re-wearable textiles. The lab is a small-scale prestige project to show the possibilities of using non-re-wearable textiles, and houses a denim school to educate young adults the skills to work with the fabrics. Since PCR fibers are shorter then virgin fibers, they have to be mixed with virgin fibers to create new fabric. The percentage of non-re-wearable textiles influences the characteristics of the fabric. House of Denim is in the process of establishing a denim-fabric brand to show clothing brands, consumers, and other stakeholders that it is possible to create high quality fashion with fabrics with a percentage of PCR fibers. House of Denim is also exploring possibilities to work with a large production factory in Spain that is distinctive in owning a shredder, a machine that can make fibers from non-re-wearable textiles (House of Denim (2015)). House of denim is contributing to the transition to CE by pushing for a new industry standard in using post-consumer fibers in all textiles. They collaborate with actors upstream in the chain by increasing their focus on materials instead of focusing on the postconsumer processes downstream.

\section{Case 5: Mud Jeans}

MUD Jeans is a Dutch denim brand that created the concept 'lease-a-jeans' as another product-as-service business model. In their business model, customers can lease a pair of jeans for $€ 7,50$ per month after paying an entrance (or membership) fee of $€ 25,-$. After one year, the customer can switch to another pair of jeans without having to pay the entrance fee again. Jeans that come back are after being worn often look good, in which case they are sold as vintage jeans. These vintage jeans then carry the story of their previous owner and are named after them. To give an example, you can buy a vintage Jeans called Marie and get the story of how Marie used the jeans. This storytelling makes the jeans more personal and exclusive, instead of simply another pair of second hand jeans (www.mudjeans.nl, 2015). When the jeans are too old to wear, MUD Jeans makes sure the jeans are shredded and fully up-cycled into new fabrics. This happens in Italy, where they have the technology to create $100 \%$ cotton fabric of which $84 \%$ is from the recycled Mud jeans. It must be noted that the production price of these sweaters in Italy is approximately four times as high as the price for a sweater made in Bangladesh (Mud Jeans, 2016). Since MUD Jeans always remains responsible for their jeans, they offer a free repair service as part of their lease (www.mudjeans.nl, 2015).

Lease-a-jeans can currently only be done on the Mud Jeans website. It is difficult to work with retail shops to get the lease-ajeans concept in stores as well. The business model of a store is to buy garments (wholesale) and sell them for a higher price (retail). Stores need to have high margins because they have high operating costs. There are two reasons why lease-a-jeans is a difficult concept for retail stores. Firstly, there is currently no solution for rewarding the retail store for leasing a pair of jeans: the lease contract is between Mud Jeans and the customer, meaning the retail store does not get a commission or other form of reward. This could possibly be solved by creating a contract or other type of arrangement to reward the retail store. Note that this would have a negative impact on the revenue of Mud Jeans, and may lead to a higher leasing fee. The second difficulty is that even if the retail store did receive a share of the lease revenue, this would lead to a slow starting cash flow. Since the store has high operating costs, this cash flow would not be able to cover these costs until they had a certain amount of lease contracts running for at least a year. That amount would then resemble the margin made when selling a pair of jeans. This is an issue that has to do with both contracting issues and financial mechanisms, and demands collaborative action to solve.

\section{Case 6: Lena Fashion Library}

Lena Fashion library is both a store where people can buy garments and a library where garments can be rented, i.e. a productas-service business model. As opposed to Mud Jeans, Lena has its own retail/library store. A library subscription costs $€ 20$, $€ 35$, or $€ 50$, per month which is respectively worth one hundred, two hundred, or three hundred points. All garments are assigned a certain amount of points (for example a dress can be 50 points and a top 30 points) and people can borrow their point-amount worth of garments. When they exceed this amount, they can pay extra. Customers can switch as often as they want and keep the garment for as long as they want: there is no rule that garments can only be in possession for a limited period. When customers wear the borrowed garments it can happen that a garment accidentally gets stained. Lena stresses the importance of care-free borrowing, and therefore customers are allowed to have 'accidents' without punishment. Moreover, if a customer decides to buy a garment after borrowing it, a discount is given on the sales price.

Lena's collection is a mix of upcoming designers, old collections of eco labels, and vintage garments. All garments in Lena are of high quality, which is a necessity when garments are worn by multiple customers. Lena exposed a divide between brands that do not want to be on display at Lena out of fear to be associated with 'second hand' garments and brands that explicitly do want to be on display at Lena because they perceive the concept as a new sustainable business model for fashion. Lena takes this latter role seriously and collaborates with motivated brands in order to make their processes more sustainable. This collaboration has started in the form of brands providing old collections in conciliation, so that Lena can pay the brands as soon as the garments are sold. This means that these brands do not receive revenues from the borrowing of garments. Currently, Lena is looking into ways to redistribute a share of the borrowing revenue to brands in order to create an incentive for brands to start lending garments instead of selling them. Lena's future goal is to increase lending capacity also outside the Lena store. The idea is to create "in-store libraries" and to stimulate an increasing amount of retail stores to start lending (part of their) collections. An integrated software system should support this network of in-store libraries by monitoring where garments are borrowed, and distributing revenues accordingly. This way retail stores taking part in this initiative will be connected, and will have a shared incentive to grow this business model (Lena the Fashion Library, 2015). When starting their business, Lena had to invest their own capital in to the project because banks did not want to finance it. Although this was a disappointment at first, it allowed the owners to remain in full control of their business. It seems financing product-as-service business models is difficult, which will be further discussed below. Seeing as their client base has 
increased to exceed their forecast, Lena Fashion Library turned out to be successful (Lena the Fashion Library, 2015).

\section{Case 7: Dutch aWEARness}

Dutch aWEARness is a business that offers circular work and corporate-wear in a service contract (i.e. a product-as-service business model). Dutch aWEARness has succeeded to heat garments in order to release the yarn, which can be a valuable technology because garments with a lot of stitching lines ${ }^{9}$ cannot yet be up-cycled. They lease the garments to businesses, offer a repair service, and stay responsible for the performance of the garments during the contractual period. After the contract ends, garments are returned to Dutch aWEARness and are repaired, reused (partly: reflecting strips et cetera), or the materials are up-cycled into new garments. Materials can be up-cycled as a result of developing a type of polyester that can be $100 \%$ up-cycled into new polyester garments. This material was developed because of close collaboration with the supply chain, and being able to attract European funding to develop the material. Moreover, the chain has put a track-and-trace system in place that can not only tell the material composition of the garments, but also shows the value added by different chain partners. More than a single brand, Dutch aWEARness garments and the functioning of the product-as-service model are seen as a joint effort of the entire supply chain. In this supply chain, Dutch aWEARness takes on the role of chain director, connecting the other supply chain actors and improving the circularity of their activities at the supply chain level. Since this new, polyester material can be used over and over again, the supply chain has an incentive to collaborate in using it over multiple life-cycles. Ownership of the polyester garments remains at Dutch aWEARness. However, Dutch aWEARness stresses that it would be better if there was a way to allocate the ownership of the materials/garments across the supply chain. This would provide the most effective incentive alignment mechanism for supply chain partners to collaborate. However, creating a contractual structure that locates ownership across supply chain is challenging. Another challenge is that Dutch aWEARness has trouble attracting funds for the product-as-service business model. Due to the slow starting cash flow and high upfront investment costs for the production process, the time gap between investing in the garments and receiving revenues (as opposed to an immediate sale) makes it difficult to finance the business model.

\section{References}

Achterberg, E., Hinfelaar, J., Bocken, N., 2016. Master Circular Business with the Value Hill. White Paper, p. 18. Report available at: http://www.circle-economy. com/wp-content/uploads/2016/09/finance-white-paper-20160923.pdf.

Anderson, T.L., Hill, P.J., 2002. Cowboys and contracts. J. Leg. Stud. 31.

Anderson, T.L., Hill, P.J., 2004. The not so wild wild west: Property rights on the frontier. Stanford University Press, Stanford CA.

Ashton, W., 2008. Understanding the organization of industrial ecosystems. J. Industrial Ecol. 12 (1), 34-51.

Ashton, W.S., 2009. The structure, function, and evolution of a regional industria ecosystem. J. Industrial Ecol. 13 (2), 228-246.

Baker, G., Gibbons, R., Murphy, K.J., 2002. Relational contracts and the theory of the firm. Q. J. Econ. 117 (1), 39-84.

Barker, T., 2007. Climate change 2007: an assessment of the intergovernmental panel on climate change. November Change 446, 12-17.

Battilana, J., Leca, B., Boxenbaum, E., 2009. How actors change institutions: towards a theory of institutional entrepreneurship. Acad. Manag. Ann. 3 (1), 65-107.

Braungart, M., McDonough, W., 2002. Cradle to Cradle; Remaking the Way We Make Things (New York)

Braungart, M., McDonough, W., Bollinger, A., 2007. Cradle-to-cradle design: creating healthy emissions - a strategy for eco-effective product and system design. J. Clean. Prod. 15, 1337-1348.

\footnotetext{
${ }^{9}$ For example the upper part of jeans have so much stitching lines, due to
} pockets and zippers, that this part is not fit for up-cycling.
Camerer, C.F., 1997. Progress in behavioral game theory. J. Econ. Perspect. 11 (4), $167-188$.

Circle Economy, 2015. H. Smits. Interview March 18th 2015.

Coase, R.H., 1988. The nature of the firm: influence. J. Law, Econ. Organ. 4 (1), 33-47. Cohen, L., Manion, L., 2000. Research Methods in Education, fifth ed. Routledge.

Costanza, R., d'Arge, R., de Groot, R., Farber, S., Grasso, M., Hannon, B., ..., van den Belt, M., 1997. The value of the world's ecosystem services and natural capital. Nature 387 (6630), 253-260 (8).

Cradle to Cradle, 2015. R. Vissers. Interview March 3rd 2015.

Dacin, M.T., Goodstein, J., Scott, W.R., 2002. Institutional theory and institutional change: introduction to the special research forum. Acad. Manag. J. 45, 45-46.

DiMaggio, P.J., Powell, W.W., 1983. The iron cage revisited: institutional isomorphism and collective rationallity in organizational fields. Am. Sociol. Rev. 48, $147-160$.

Eisenhardt, K.M., Graebner, M.E., 2007. Theory building from cases: opportunities and challenges. Acad. Manag. J. 50 (1), 25-32.

Ellen MacArthur Foundation and McKinsey, 2014. Towards the Circular Economy: Accelerating the Scale-up across Global Supply Chains, Rapport. World Economic Forum, Switzerland.

Ellen McArthur Foundation, 2013. Towards the Circular Economy Vol. 1: an Economic and Business Rationale for an Accelerated Transition, p. 96. Report available at: http://www.ellenmacarthurfoundation.org/publications.

FFACT, 2014. Mass Balance of Collected and Imported Textiles in the Netherlands (translated from: Massabalans van in Nederland ingezameld en geïmporteerd textiel). FFact Strategy and Implementation, Delft.

Gallopoulos, N.E., 2006. Industrial ecology: an overview. Prog. Industrial Ecol. Int. J. $3(1-2), 10-27$.

Ghisellini, P., Cialani, C., Ulgiati, S., 2016. A review on circular economy: the expected transition to a balanced interplay of environmental and economic systems. J. Clean. Prod. 114, 11-32.

Grandori, A., 1997. An organizational assessment of interfirm coordination modes. Organ. Stud. 18 (6), 897-925.

Grandori, A., Soda, G., 1995. Inter-firm networks: antecedents, mechanisms and forms. Organ. Stud. 16 (2), 183-214.

Grandori, A., 2012. Interfirm Networks: Organization and Industrial Competitiveness. Routledge.

Grant, R.M., Baden-Fuller, C., 1995. A knowledge-based theory of inter-firm collaboration. Acad. Manag. 1995 (1), 17-21.

Greif, A., 1998. Historical and comparative institutional analysis. Am. Econ. Rev. 88, 80-84.

Groot, R.S., De, Wilson, M.A., Boumans, R.M.J., 2002. A typology for the classification, description and valuation of ecosystem functions, goods and services. Ecol. Econ. 41, 393-408.

House of Denim, 2015. J. Veenhoff. Interview April 9th 2015.

Korhonen, J., 2001. Co-production of heat and power: an anchor tenant of a regional industrial ecosystem. J. Clean. Prod. 9 (6), 509-517.

Korhonen, J., 2004. Industrial ecology in the strategic sustainable development model: strategic applications of industrial ecology. J. Clean. Prod. 12 (8), 809-823.

Lena the Fashion Library, 2015. S. Smulders, Interview April 4th 2015.

Lewandowski, M., 2016. Designing the business models for circular economy-towards the conceptual framework. Sustainability 8 (1), 43.

Lozano, R., Carpenter, A., Huisingh, D., 2014. A review of 'theories of the firm'and their contributions to Corporate Sustainability. J. Clean. Prod. 106, 430-442.

Murray, A., Skene, K., Haynes, K., 2015. The circular economy: an interdisciplinary exploration of the concept and application in a global context. J. Bus. Ethics $1-12$.

North, D., 1990. Institutions, Institutional Change, and Economic Performance. Cambridge University Press, Cambridge UK.

Ostrom, E., 1995. Understanding Institutional Diversity. Princeton University Press, Princeton, New Jersey.

Ostrom, E., 2011. Background on the institutional analysis and development framework. Policy Stud. J. 39 (1), 7-27.

Ostrom, E., Gardner, R., Walker, J., 1994. Rules, Games, and Common-pool Resources, University of Michigan Press.

Pacheco, D.F., York, J.G., Dean, T.J., Sarasvathy, S.D., 2010. The coevolution of institutional entrepreneurship: a tale of two theories. J. Manag. 36 (4), 974-1010.

Preston, F., 2012. A global redesign? shaping the circular economy. Energy, Environ. Resour: Gov. 2, 1-20.

Slangen, L.H.G., Loucks, L.A., Slangen, A.H.L., 2008. Institutional Economics and Economic Organization Theory; an Integrated Approach (Wageningen).

Smol, M., Kulczycka, J., Henclik, A., Gorazda, K., Wzorek, Z., 2015. The possible use of sewage sludge ash (SSA) in the construction industry as a way towards a circular economy. J. Clean. Prod. 95, 45-54.

Toxopeus, M.E., de Koeijer, B.L.A., Meij, A.G.G.H., 2015. Cradle to cradle: effective vision vs. Efficient practice? Procedia CIRP 29, 384-389.

Tukker, A., 2013. Product services for a resource-efficient and circular economy-a review. J. Clean. Prod. 97 (15), 76-91.

Turntoo, 2015. D. Appleton. Interview March 17th 2015.

van Weelden, E., Mugge, R., Bakker, C., 2016. Paving the way towards circular consumption: exploring consumer acceptance of refurbished mobile phones in the Dutch market. J. Clean. Prod. 113, 743-754.

Verfaillie, H.A., Bidwell, R., 2000. Measuring Eco-efficiency: a Guide to Reporting Company Performance. World Business Council for Sustainable Development (June). 
Wassenaar, T., 2015. Reconsidering industrial metabolism: from analogy to denoting actuality. J. Industrial Ecol. 19 (5), 715-727.

Williamson, O.E., 2000. The new institutional economics: taking stock, looking ahead. J. Econ. Literature 38 (3), 595-613.

Williamson, O.E., 2002. The theory of the firm as governance structure: from choice to contract. J. Econ. Perspect. 171-195.

Working Group FinanCE, 2016. Money Makes the World Go Round - and Will it Help to Make the Circular Economy as Well, Working Group FinanCE, Affiliated with the Ellen MacArthur Foundation.

\section{Websites:}

http://srmo.sagepub.com, retrieved May 28th 2015

http://biomimicry.net, retrieved February 10th 2015 http://www.circle-economy.com, retrieved April 20th 2015

http://www.circle-economy.com/textiles/, retrieved September 13th 2016

http://www.circle-economy.com/case/circlemarket/, retrieved September 13th 2016

http://www.duurzaamnu.nl/archives/176-Belasting-als-sturingsinstrument.html, retrieved May 6th 2015

www.mudjeans.nl, retrieved April 20th 2015

http://www.rtlnieuws.nl/economie/nma-geeft-boetes-voor-oude-kartelvormingaan-kpn-vodafone-en-t-mobile, retrieved May 30th 2015

http://textilelab.nl/, retrieved 11th November 2015

http://www.theoptimist.nl/een-duurzame-vrije-markt, retrieved May 6th 2015

http://www.wbs.nl/platform/debatten/4431/start-eerst-eens-met-een-

hervorming-van-het-belastingstelsel, retrieved May 6th 2015 